\title{
Insecticidal Efficacy Of African Rock Fig Leaf Powder (Ficus Congensis Engl.) Against The Croundnut Bruchid (Caryedon Serratus Olivier) On Stored Groundnut In Yola.
}

\author{
${ }^{1}$ Oaya, C.S., ${ }^{2}$ Malgwi, A. M. And ${ }^{3}$ Samaila, A. E. \\ ${ }^{1}$ Department of Agricultural Technology Adamawa State College of Agriculture, P. M. B. 2088, Ganye, \\ Adamawa State. \\ ${ }^{2}$ Department of Crop Protection, Modibbo Adama University of Technology, P. M. B. 2076, Yola, Adamawa \\ State. \\ ${ }^{3}$ American University of Nigeria Lamido Zubairu Way, P.M.B. 2250, Yola, Adamawa State, Nigeria.
}

\begin{abstract}
The insecticidal efficacy of the African rock fig leaf powder, (Ficus congensis Engl.) as an alternative source of control against the groundnut bruchid (Caryedon serratus Olivier) on stored groundnut was evaluated in the Laboratory of the Department of Crop Production and Horticulture/Crop Protection, Modibbo Adama University of Technology, Yola. The results obtained reveals that, the plant material leaf powder had a remarkable effects on all the parameters measured. The least mean percentage damaged seeds was observed in the chemical actellic dust at $1 \mathrm{~g} / 100 \mathrm{~g}$ seeds (7.00), followed by Ficus congensis Engl. leaf powder at 8.0g/100g seeds (19.00) and the highest was recorded in the control (80.33). The highest mean percentage undamaged seeds and the least mean percentage weight loss was seen in the chemical actellic dust at $1 \mathrm{~g} / 100$ seeds (93.00 and 8.00) followed by plant material leaf powder at 8.0g/100g seeds (81.00 and 13.67) and the least and the highest was in the controls (19.67 and 61.75) respectively. It was also found out that, the plant material, Ficuscongensis Engl. is a promising candidate for developing botanical, biodegradable and ecologically friendly insecticides and could replace the use of synthetic insecticides on a small farmers holding. The study further stressed that, the impact on the stored product depends on the quantity or dosage level. This shows that, the higher the quantity of the leaf powder, the more effective the plant material was. Therefore, the leaf powder is recommended for storing groundnut for at least 12 weeks at the rate of $8.0 \mathrm{~g} / 100 \mathrm{~g}$ grain. All the treatments had significant control of the bruchid compared to the controls at $P \leq 0.05$ level of significance using the Student Newman-Keuls (SNK) test for variables.

Key Words: Damage, Bruchid, Pest, Mortality, Control, Groundnut, Oviposition.
\end{abstract}

\section{Introduction}

Groundnut (Arachis hypogea Linn.) also known as peanut earthnut, gobbers, pinders, etc. belongs to the family leguminosae (Fabacea) (Beghnin and Sewadah, 2003). Other members of this family include cowpea, soyabeans, tamarind, melon etc. (Ashley, 1993). Groundnut originated from South America (Brazil) and was introduced into Nigeria by the Portuguese after the $16^{\text {th }}$ century (Adeyemi, 1968). Groundnut production in Africa has been estimated at 4.6 metric tons, with Nigeria being the major producer in Africa (Ashley, 1993). According to Nyilra (1988), Nigerian's production of unshelled nut is about 2.6 metric tons annually from a land area of approximately 2.5 million hectares. Groundnut thrives best on a well-drained sandy-loam soil, this type of soil facilitates easy penetration of pegs and their development, hence their harvesting (Yayock, 1984).

Weiss (2000) suggested that, temperature range of $25-30^{\circ} \mathrm{c}$, rainfall of $500-1000 \mathrm{~mm}$ and a pH range of $6.0-6.5$ is considered optimum for groundnut production. Groundnut is a major cash crop which serves as a foreign exchange earner prior to the petroleum boom in Nigeria (Adeyemi, 1968). According to Aribisala (1993), the crop is a good source of protein, fats and oil, vitamins etc. Shelled groundnuts are fried, roasted and salted which is eaten as snacks. The crop serves as raw materials for some food industries and also as feed concentrate for livestock (David and Adamu, 1988).

Groundnut is vulnerable to pest attack throughout its growing stage and in store, though the extent of insect damage varies from one agro-ecological zone to the other (Hooker, 1991). In northern Nigeria alone, yield loss of groundnut due to Caryedon serratus Olivier infestation is estimated at 150,000 - 250,000 tons annually, about 35\% loss resulting to several million naira loss to the country (IITA, 2000).

The extent of post-harvest losses has prompted several studies of insect pests population development on groundnut in store. However, few or no attempts have been made to measure the degree of losses caused by these insects (Caryedon serratus Olivier) either in farmers store or in a large scale commercial storage in Nigeria. Consequently, there is inadequate information on appropriate methods for assessing post-harvest losses especially among the local farmers. The control of insect pests with synthetic insecticides is popular and 
effective (Oparacke et al., 2000). However, improper usage as a result of low technical know-how led to high mammalian toxicity, persistence in the soil and pollution of the environment (Degri, 1997). The high import bills incurred, accentuated by devaluation of local currencies, not only pose a serious drain on the economy but also make synthetic insecticides unaffordable to limited resources farmers (Perkings, 1982). Insecticides of plant origin as alternative to synthetics are being investigated all over the world to develop less harmful ecologically tolerable but effective plant derived control strategy (Anaso et al., 1998). The African rock fig (Ficus congencis Engl.) leaf powder was used as an alternative to synthetic insecticide against the groundnut bruchid (Caryedon serratus Olivier) on stored groundnut. Generally, plants have evolved highly elaborate chemical defenses against the insect pest attack and they have therefore provided a rich source of biologically active chemical compounds which may be used as protectants (Adedire et al., 2000).

\section{Materials And Methods.}

The experiment was carried out in the Laboratory of the Department of Crop Production and Horticulture, Federal University of Technology, Yola. The University is located in Sangere village, Girei Local Government area, within longitude $9^{\circ} 14^{\prime \prime}$ North and latitude $12^{\circ} 13^{\prime}$ East of the equator in the Northern Guinea Savannah agro-ecological zone of Nigeria (Adebayo, 1999). Ten paired, clean freshly emerged adult Caryedon serrates Olivier were introduced into storage jars already containing 100 grams of the stored products (groundnut) to which $2.0 \mathrm{~g}, 4.0 \mathrm{~g}, 6.0 \mathrm{~g}, 8.0 \mathrm{~g}$ of the plant material leaf powder and the chemical (actellic dust) at $1 \mathrm{~g} / 100$ seeds had been added. The initial weight of the stored products was taken and the moisture content of the seeds used was $11-12 \%$. There were six (6) treatments replicated three (3) times arranged on the table in the Laboratory at a room temperature of $38-39^{\circ} \mathrm{c}$ and relative humidity of $40-45 \%$. The experimental design used was the Completely Randomized Design (CRD). Deadbruchids were removed at the end of the experiment and the results taken.

The groundnut used was the local variety found in the study area popularly known as the "kampalla" and it was obtained locally from the farmers in the village and they were sorted out to remove injured or infested ones with pests. The adults Caryedon serratus Olivier were collected from infested seeds of groundnut and tamarind maintained or cultured in a large stock. The age of the test insects used was standardized by collecting the larvae that were about to emerge within the range of $0-24 \mathrm{hrs}$ old. This gave room for uniform oviposition period and the number of eggs laid thereafter. The storage jars used were covered with muslin cloth in order to prevent the bruchid from escaping, which is a typical condition most subsistence farmers store their crops for immediate consumption.

\section{FORMULAE USED}

\begin{tabular}{|c|c|c|c|}
\hline Percentage damaged seeds & $=$ & $\frac{\text { Number of damaged seeds }}{\text { Initial number of seeds }}$ & $\mathrm{X}$ \\
\hline $\begin{array}{l}\text { Percentage undamaged seeds } \\
\text { Initial number of seeds }\end{array}$ & $=$ & $\underline{\text { Number of undamaged seeds }}$ & $\mathrm{X}$ \\
\hline $\begin{array}{l}\text { Percentage mortality } \\
\text { Total number of bruchids alive and dead }\end{array}$ & $=$ & Number of dead adult bruchids & $\mathrm{X}$ \\
\hline $\begin{array}{l}\text { Percentage weight loss } \\
\text { Initial weight }\end{array}$ & $=$ & Initial weight - final weight & X \\
\hline
\end{tabular}

Source $=$ Dick (1987).

Data collected were subjected to the analysis of variance (ANOVA) appropriate to Completely Randomized Design according to Gomez and Gomez (1984). Means were separated using the Student Newman -Keuls (SNK) at $\mathrm{P} \leq 0.05$ according to Fisher and Hedge (1935).

\section{Results}

The highest mean percentage damaged seeds were observed in the control (80.31), followed by $2.0 \mathrm{~g}$ (39.00), $4.0 \mathrm{~g}$ (32.00), 6.0g (25.00), 8.0g/100g seeds (19.00) of the plant material leaf powder (Ficus congensis Engl.) and the least was recorded in the groundnut (7.00) administered with actellic dust at $1 \mathrm{~g} / 100$ seeds as seen in Table 1 at $\mathrm{P} \leq 0.05$ using the Student Newman-Keuls (SNK) test for variables. Groundnut stored with the chemical actellic dust gave the highest mean percentage undamaged seeds (93.00), followed by groundnut stored with $8.0 \mathrm{~g}(81.00) 6.0 \mathrm{~g}(75.00), 4.0 \mathrm{~g}(68.00), 2.0 \mathrm{~g}(61.00)$ levels of the plant material leaf powder and the least was observed in the control (19.67). Chemical means of control (actellic dust) also gave highest mean percentage mortality (91.00) closely followed by groundnut stored with 8.0g (86.00), 6.0g (81.68), 4.0g (77.33), $2.0 \mathrm{~g}(69.10)$ of the plant material leaf powder at $100 \mathrm{~g} / \mathrm{seeds}$ and the least was obtained in the control (8.67). 
Table1: Mean Percentage Damageed Seeds, Undamaged Seeds and Mortality.

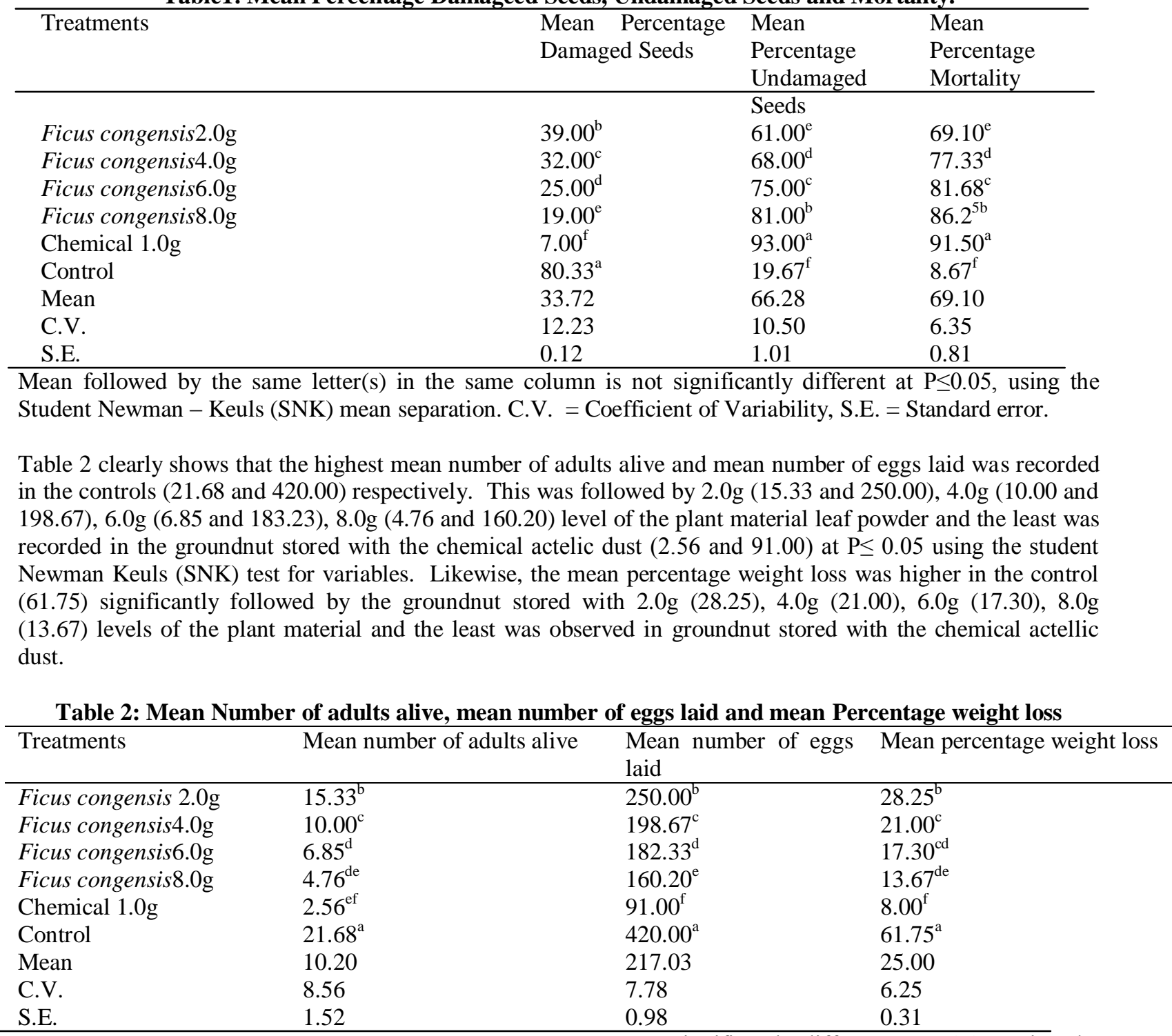

Mean followed by the same letter(s) in the same column is not significantly different at $\mathrm{P} \leq 0.05$, using the Student Newman - Keuls (SNK) mean separation. C.V. = Coefficient of Variability, S.E. = Standard error.

\section{Discussion}

The storage problems of crops in this country are not new forcrops like groundnut and other legumes. It's apparent that, storage without the use of synthetic chemicals is a futile exercise, however, its toxic and detrimental effects to man, his livestock and the residual damage done to the entire environment is of great concern (Zetteretal., 1997).

The 100 grams of groundnut was subjected to varying levels of plant material leaf powder $(2.0 \mathrm{~g}, 4.0 \mathrm{~g}$, $6.0 \mathrm{~g}, 8.0 \mathrm{~g}$ ) and chemical actellic dust using the following parameters, mean percentage damaged seeds, mean percentage undamaged seeds, mean percentage mortality, mean number of adults alive, mean number of eggs laid and mean percentage weight loss. The results as presented in Tables 1 and 2 shows that, the chemical means of control gave the best control as it had the less mean percentage damaged seeds, high mean percentage undamaged seeds and high mean percentage mortality. This was because chemical control is still the most effective means of insect pest control (Daglish et al; 1993; Singh, 1990). Chemicals are toxic to the target at some stages of its life cycle (Dick, 1987). They are compound with repellant effects and may not necessarily be actively poisonous but render the seeds unattractive to the pest by virtue of their ordour, taste or physical properties (Zetter et al., 1997). The four levels of the plant material leaf powder $(2.0 \mathrm{~g}, 4.0 \mathrm{~g}, 6.0 \mathrm{~g}$, and $8.0 \mathrm{~g}$ ) also significantly reduced the egg laying ability and suppressed adult emergence. This agrees with the finding by Ofuya et al., (2001), that plant material powder with toxic constituents are effective in suppressing egg laying ability and the observed results could be a direct consequence of reduction in egg production or inhibition of egg 
laying or both. This means that, the plant material Ficus congensis Engl. has insecticidal properties and effects that inhibit egg laying and hatching which agrees with Zizka (2008), who stated that, the repellant and the pungent ordour produced by the plant material powder inactivates the bruchids as a result, their ability to bore into the seed was highly minimized. There was also less weight loss recorded in plant material leaf powder treated seeds. This agrees with Lale (2003), that the presence of the protective powder around the stored product reduces the weight loss by $14 \%$.

The dosage level or the quantity of the plant material leaf powder used also significantly affected the results obtained. 100grams of groundnut treated with 8.0g of the Ficus congensis Engl. leaf powder caused 86\% mortality, $19 \%$ damage and only $13 \%$ of the weight lost. This train continues in a descending order as the quantity of the plant material leaf powder is reduced from $8.0 \mathrm{~g}, 6.0 \mathrm{~g}, 4.0 \mathrm{gand}$ up to $2.0 \mathrm{~g}$ respectively. This clearly means that, the higher the quantity of the leaf powder the more effective the plant material was. This agrees with Otitodun (2001), who reported that, the dosage level of the protectant is directly proportional to the impact made on both the test insect and the stored product. There was therefore a significant difference among the treatments treated with the plant material leaf powder.

\section{Conclusion}

Although, many studies have addressed the insecticidal efficacy of protectants of plant origin, this may be the first time that, the leaf powder of the African rock fig (Ficus congensis Engl.) have been evaluated for insecticidal and oviposition deterrence activity particularly in the study area. This study has shown that, the plant material is a promising candidate for developing botanical, biodegradable and ecologically friendly insecticides, which could be used at small holder farmers against the groundnut bruchid (Caryedon serratus Olivier) on stored groundnut since it is effective and safe for human consumption. They are easily obtained and can be integrated with other pest management procedures.

\section{Recommendation}

The results obtained from this research work reveals that, the African rock fig leaf powder (Ficus congensis Engl.) gave a significant control of the groundnut bruchid (Caryedon serratus Olivier) on stored groundnut. The leaf powder is therefore recommended for groundnut storage for at least 12 weeks giving the grains perfect state of wholesomeness required at the rate of $8.0 \mathrm{~g} / 100 \mathrm{~g}$ grain.

\section{References.}

[1] Adebayo, A.A. (1999). Climate II In: Adebayo, A.A. and Tukur, A.L. (eds) 1999 Adamawa State in Maps. Pp. 23-25. Paraclete Publishers, JimetaYola.

[2] Adedire, C. O. and Lajidire, L., (2000). Toxicity and Oviposition Deterancy of some Plant extracts on cowpea Storage BruchidCallosobruchusmaculatus Fab. Journal of Plants Diseases and Protection 106, 547 -651.

[3] Adeyemi, S.A. (1968). Storage Entomology; Proceedings of Agricultural Society of Nigeria. Vol. 34.

[4] Ashley, J. (1993). Drought and Crop Adaptation InDry Land Farming in Africa (Rowland, R.J. ed). Macmillan Education Ltd. London Pp. 10.

[5] Beghnin, J. Diop, N. and Sewadah, M. (2003).The Impact of Groundnut Trade Liberalization. Tim Hill Publishing company Limited India. Pp. 241-242.

[6] Daglish, G.J. Erbacher, J.M. and Elkema, N. (1993). Efficacy of Protectants AgainstCallosobruchusphaseoli (Gyll) and C. maculatus (F) (Coleoptera: Bruchidae) in Mungbeans

[7] David, G. and Adamu, P. (1988).Crops of the Drier Regions of the Tropics. Longman Group Ltd., London. P. 157.

[8] Degri, M.M. (2000). Comparative Efficacy of Some Insecticides for the Control of Leaf Footed Bug, LeptoglossusAustralist (F.) on Stored Cowpea. Entomological Society of Nigeria. (32): 191-194.

[9] Dick, K.M. (1987). Pest Management in Stored Groundnut. Chapman and Hall, London. Pp. 365.

[10] Hooker, J.D. (1991). The Flora of British India.Viol. II. L. Reeve and company Ltd, London. 25Pp.

[11] IITA (International Institute for Tropical Agriculture) (2000).Field Crop Production.Annual Report. IITA Publication, Ibadan Nigeria. P. 10.

[12] Lale, N.E.S. (2002). Stored Product Entomology and Acarology in Tropical Africa.Mole Publication Nigeria Ltd. Pp.50-60.

[13] Nyilra, N.Z. (1988). Pest of Grain Legumes and theirCcontrol in Uganda. Academic Press, London. Pp. 22-24.

[14] Ofuya, T.I. and Lale, N.E.S. (2001).Pest of Stored Cereals and Pulses in Nigeria.Dake Collins Publications, Akure-Nigeria. Pp. 3042.

[15] Oparakere, A.M., Dike, M.C. and Amatobi, C.I. (2000). Insecticide Potential of Extracts of Garlic, Allium sativum (Linneaus) Bulb and African Nut-meg,Monodoramytristixc (Gaetn) Dunal Seed for Insect Pest Control on Cowpea.

[16] Otitodun, O.G. (2001). Six Plant Powders as Protectants of Stored Cowpea against Callosobruchusmaculatus Fab. Nigeria Journal of Plant Protection 19(2000/2001): 23-30.

[17] Perkings, H.H. (1982). Insects Expert and the Insecticides Crisis. Plenum Press, New York. In: Raheja, A.K. 1976. Assessment of Losses Caused By Insects Pests of Cowpea in Northern PANS, 22:229-233.

[18] Singh, S.R. (1990). Host Plant Resistance for cowpea Insect Pest Management.Insect Science and its Application 8: $765-768$.

[19] Weiss, E.A. (2000). Oil Seed Crop..Blackwell Publishers, London. UK. 16.

[20] Zetter, J.I. Leesch, J.G. Gill, R.F. and Markey, B. E. (1997).Toxicity of Cabaryl Sulfide to Stored Product Insects.Journal of Economic Entomology.90: 832-834.

[21] Zizka, G. (2008). West African Plants.Macmillan Press Ltd. London.Pp. 15. 